\title{
Flint's Molinism and the Incarnation is too Radical
}

\author{
R.T. Mullins \\ University of Cambridge
}

\begin{abstract}
In a series of papers, Thomas P. Flint has posited that God the Son could become incarnate in any human person as long as certain conditions are met (Flint 2001a, 2001b). In a recent paper, he has argued that all saved human persons will one day become incarnated by the Son (Flint 2011). Flint claims that this is motivated by a combination of Molinism and orthodox Christology. I shall argue that this is unmotivated because it is condemned by orthodox Christology. Flint has unknowingly articulated a version of the heresy called Origenism that is condemned by the Fifth Ecumenical Council. After arguing that Flint's account is unmotivated because it is condemned, I shall offer some reflections and prolegomena on the relationship between contemporary analytic theology and the ecumenical creeds.
\end{abstract}

Thomas P. Flint maintains that any human person could become incarnate, and that one day all of redeemed humanity will become incarnate. He maintains that this position is motivated by, and compatible with, orthodox Christology, the teachings of the Catholic Church, and Molinism. By orthodox Christology, Flint means the teachings of the seven ecumenical councils: Nicaea I (325), Constantinople I (381), Ephesus (431), Chalcedon (451), Constantinople II (553), Constantinople III (68081), and Nicaea II (787). I gather that the teachings of the Catholic Church includes the writings of major theologians like Thomas Aquinas, as well as a whole assortment of Catholic synods, councils, and catechisms. Molinism is a position on God's omniscience and providence that claims that God has middle knowledge, and that God uses this middle knowledge to providentially govern the world. ${ }^{1}$

In section I of this paper I shall articulate Flint's account of Christology and the future heavenly incarnation of the redeemed. Flint calls this future heavenly incarnation "The Theory of the Final Assumption." In section II, I shall argue that Flint's Christology violates the teachings of the Fifth Ecumenical Council, Constantinople II. So Flint's Christology is not compatible with orthodox Christology. As such, it cannot be motivated by orthodox Christology, thus leaving Flint's Christology unmotivated. In section III, I shall examine Flint's eschatology of The Theory of the Final Assumption. Flint claims that The Theory of the Final Assumption is motivated in part by his Christology. Since his Christology is not

${ }^{1}$ I shall assume that readers are familiar enough with Molinism that I do not need to offer an articulation of the doctrine. Readers unfamiliar should see Flint (1998).

Journal of Analytic Theology, Vol. 3, May 2015

10.12978/jat.2015-3.17-51-51122018a

(C)2015 R.T. Mullins • (C) 2015 Journal of Analytic Theology 
orthodox, and thus unmotivated, The Theory of the Final Assumption is also unmotivated. I shall argue that The Theory of the Final Assumption is not only unmotivated, but that it also violates the teachings of the Fifth Ecumenical Council. This is because Flint's doctrine looks like the heresy of Origenism. In section IV, I shall offer some reflections and prolegomena on the relationship between the ecumenical creeds and contemporary philosophical theology.

\section{Flint's Christology and Eschatology}

Flint wishes to maintain a Christology that is compatible with the claims of the seven ecumenical creeds and Catholic teaching. One important aspect of the ecumenical creeds is the claim that Jesus Christ is the second Person of the TrinityGod the Son-who has become incarnate in human flesh. Jesus is fully God and fully man. Jesus has a complete divine nature, and a complete human nature. Flint spells this out as follows.

A human nature consists of a concrete soul and body. God the Son assumed a complete human nature. Call it CHN for Christ's human nature. According to Flint, the doctrine of the incarnation needs to hold to The Metaphysical Presupposition (TMP). What is TMP? Flint explains as follows.

In becoming incarnate, the Son united to himself a complete individual human nature. What he brought into union with himself was a concrete created thing that had, so to speak, all the parts and all the faculties that we ordinary human beings have-a thing that would itself have been a human person had it not been assumed by a divine person (Flint 2011, 189).

Flint maintains that TMP is a fairly common view in church history. Later I shall call that into question. For now, it will suffice to point out that, according to Flint, CHN would have been a human person if the Son had not assumed CHN in the incarnation.

Flint further claims that any human person can be assumed so long as they never sin. Via God's middle knowledge, God knows which human persons would not sin in certain worlds. Human persons that do not sin in a particular world are assumable. For instance, say there is a world where Bill Clinton does not sin. In that world, Bill Clinton is assumable. The Son could assume Bill Clinton if He so desires. Now, you might be thinking to yourself, "But Bill Clinton is a person. According to Christian orthodoxy, the Son assumed a human nature, not a person. So the Son can't assume Bill Clinton." Flint is way ahead of you on this. According to Flint, and allegedly the medieval Christian philosophers and theologians, a human nature is a person so long as they are not assumed by a divine person. The instant that the Son assumes Bill Clinton, Bill ceases to be a person and becomes an assumed human nature of the Son. It is the assumption relation, or the hypostatic union, that overrides Bill's personhood. 
What is this assumption relation? It is some relation that a divine person has to a human nature that somehow renders this human nature not a person. Instead, because of this assumption relation, there is only one person-the divine personwith a fully divine nature and a fully human nature. The natures are somehow perfectly united in the one Person, God the Son, such that there is only one person and not two. How does this assumption relation work? How is it any different from God's relationship to the rest of humanity? Flint does not say, nor does Church tradition. The assumption relation is typically taken to be an ineffable mystery. For instance, Cyril of Alexandria says that this ineffably mysterious relation is what distinguishes his view from Nestorianism $(1980,326)$. Cyril's teaching on this point is adopted by Chalcedon, but one should not think that leaving the hypostatic union as an ineffable mystery was desired by all in attendance at Chalcedon. There was internal and external pressure to achieve a more precise statement, but no agreement among the participants on this point could be found. As a result, Chalcedon leaves the union completely ambiguous and undefined (Coakley 2002). This ambiguity led to further divisions in the Church, and the need to call more ecumenical councils together to attempt to develop more precise Christological definitions. How appealing to ineffable mysteries helps distinguish orthodoxy from heterodoxy is beyond me. After Chalcedon, the theologians in the East certainly did not think that this ineffably mysterious assumption relation distinguished Chalcedonian Christology from Nestorianism. ${ }^{2}$ However, I must set aside any criticisms of ineffable mysteries. I shall simply point out that, historically, theological appeals to ineffable mysteries have not always been seen as desirable, nor helpful. Further, in leaving the assumption relation ambiguous, Flint is merely following a long Church tradition.

With this in mind, we can turn to the next feature of Flint's Christology. Flint proposes 6 Radical Theses (Flint 2011, 191). ("Radical" is his term, not mine.) Again, Flint claims that these theses are compatible with the ecumenical councils, and are motivated by Molinism and orthodox Christology. The theses are as follows:

Thesis 1: Necessarily, being assumable is a contingent feature of any assumable human nature.

Thesis 2: It's possible that CHN was neither assumed nor assumable.

Thesis 3: It's possible that there be an individual human nature distinct from CHN that was both assumable and assumed.

Thesis 4: It's possible that CHN exist as an independent, unassumed suppositum.

Thesis 5: There are in the actual world individual human natures distinct from CHN that were assumable.

Thesis 6: Necessarily, every human nature is possibly assumed.

It is worth explaining what Thesis 4 means. On Flint's schema, if CHN exists as an independent, unassumed suppositum, $\mathrm{CHN}$ is a person. Thesis 4 is saying that it is possible that CHN exist as a person completely independent of the Son. (Again, I

\footnotetext{
${ }^{2}$ For discussion, see Torrance (1988).
} 
shall call this into question later.) As noted above, for Flint, a human nature only counts as a person if it is not assumed by a divine person. Flint holds to (Q) and (R):

(Q) Any human nature that has the property of being a person could subsequently lack that property.

(R) Any human nature that has the property of being a person has it nonessentially (Flint 2011, 202)

Given the above, Flint claims that it is plausible that all human persons, or at least the elect, will one day be assumed by God the Son. He calls this the Theory of Final Assumption (TFA). According to TFA, "The ultimate end of all human beings who attain salvation is to be assumed by the Son." God has made us in such a way that all of our efforts, whether we realize it or not, are directed towards union with God. "This union will ultimately become as metaphysically real as is the union between CHN and the Son." This union doesn't come easy. We human persons must reach a state where we will no longer sin in order to be fit for assumption. Thankfully, God's grace will help us in this process of sanctification until we reach that assumable state. At that point, the Son will assume us all (Flint 2011, 198).

Given the assumption relation, a peculiar state of affairs obtains. Flint is quite upfront about this fact. Prior to the elect being assumed, all of the elect exist as human persons. Once the elect are assumed, they cease to be human persons. "For the theory implies that each human nature that is ultimately assumed by the Son is, prior to the act of union, a human nature that exists on its own, and hence a human person. And, of course, all those whose ultimate end is not heaven (if there are any such persons) remain distinct persons forever" (Flint 2011, 199).

On the face of it, TFA seems wildly implausible. Typically, Christian theologians wish to say that the ultimate end of human persons is to glorify God and enjoy Him forever. On Flint's account, the ultimate end of human persons is the nonexistence of human persons! There will be no human persons in the final eschatological state for they will all be assumed. Unless, as Flint notes, some end up in hell. If some human persons fail to be sanctified, they will remain persons, but will do so in hell. So the fate of human persons seems bleak. Human persons will either cease to exist, or burn in hell. Not much for human persons to look forward to.

This might sound like a crass caricature of Flint's position. Perhaps it is a bit crass, but it is accurate. If you are like me, you are probably worried about losing your personhood in heaven. Flint tells us not to worry. You will continue to think, feel and act of your own accord. You will retain your body, but it will be a glorified body. You shall retain your intellect and your will, but your intellect shall be sharper, and you shall be able to grasp truths more clearly. You can even continue to accurately refer to yourself in the first-person as "I." You just won't be a person anymore (Flint 2011, 205). The only persons present will be divine persons, and whoever happens to be in hell.

This is a rather odd, and I say implausible, position. At the very least, Flint is aware of the oddity. However, there is another oddity in this eschatological state that Flint does not seem to realize. The oddity is this: if you kick me, you kick Jesus. 
Allow me to explain. On an orthodox understanding of the incarnation, the Son is the ultimate bearer of the properties from His human and divine natures. This is called the communicatio idiomatum - the communication of the properties onto the one person. At present, if you were to kick CHN, you will have thereby kicked God the Son. Ultimately, the Son bears the property having been kicked. Also, at present, if you kick my body, you will have kicked me. You will not have kicked the Son. I bear the property having been kicked. When we reach the eschaton, however, things will be different. If you kick me, you will have kicked the Son. If the Son assumes my human nature, I cease to be a person. Through the communicatio idiomatum, the Son becomes the ultimate bearer of the properties of all the assumed human natures. So if you kick me in heaven, you will have ultimately kicked Christ. If I kick you in return, I will have kicked Christ. Given the communicatio idiomatum, Christ will have kicked Christ, and Christ will have responded to this kick by kicking Christ. That seems ludicrous.

However implausible I find these claims, I shall set that aside. Instead, I shall argue that Flint's Christology is not compatible with orthodox Christology because it violates the teachings of the Fifth Ecumenical Council. Since it is not compatible with orthodox Christology, Flint's Christology and eschatology cannot be motivated by orthodox Christology as Flint claims. Further, I shall argue that Flint's eschatology also violates the teachings of the Fifth Ecumenical Council.

\section{Flint's Christology Violates the Teachings of the Fifth Ecumenical Council}

In this section I wish to undermine the motivation for Flint's Christological proposal. In particular, I shall explain that TMP is false given the teachings of the Fifth Ecumenical Council. If TMP is false, Flint's 6 Radical Theses are either false, or unmotivated.

Flint claims that TMP is widely assumed in Church history. Again, TMP is the claim that the human nature of Christ could, and would have, been a human person if the Son never assumed it. To restate this in slightly different terms, consider the following. Call our world, World A. It is the actual world. In World A, CHN does not exist without being assumed by the Son. On Flint's proposal, God used His middle knowledge to select this world. Plausibly, one reason for God to select this world is because God saw that CHN would never sin in World A. CHN is a ripe candidate for assumption. But there is also World B. This is a world that God could have actualized, but He chose not to. In World B, CHN is not assumed. CHN is born of the Virgin Mary, becomes a revolutionary preacher, and proclaims the coming kingdom of God. However, in World B CHN is not assumed, so CHN is a human person that is a completely distinct person from God the Son.

Recall that Flint claims that TMP is consistent with orthodox Christology. Is it? I say no, for Flint has overlooked the Christological developments that took place after Chalcedon. In particular, he has overlooked the Christological developments that surrounded the Fifth Ecumenical Council at Constantinople. 
What must be understood is that the Council of Chalcedon did not really settle many theological debates, nor did it create the Church unity that it sought. As noted above, after the Formula of Chalcedon was framed, many in the East remained unconvinced that there was a clear difference between the defenders of Chalcedon and the Nestorians. ${ }^{3}$ Christopher Beeley explains that the Chalcedonian definition, which was enforced under governmental pressure, "left the basic identity of Christ and the nature of the union disastrously ambiguous from the point of view of the more unitive traditions. It is no wonder that Nestorius reportedly felt vindicated by the result" (Beeley 2012, 284). While many in the East were distraught over the result of Chalcedon, various Nestorian parties felt that they were able to interpret Chalcedon in such a way that they could agree to the Formula. In fact, one of the main motivations for the Fifth Ecumenical Council, Constantinople II (553), was to give a proper interpretation of Chalcedon that fully excluded Nestorianism (Sanders 2007, 27-35). The Eastern church made a serious push to get single-nature Christologies included in the scope of orthodoxy, and the emperor Justinian was keen to make peace with these groups from the East (Beeley 2012, 294).

One of the most important developments during this time period is the anhypostasia and enhypostasia distinction. This is a distinction that developed in the aftermath of Chalcedon leading up to the Fifth Ecumenical Council. The distinction was developed in an effort to rid ecumenical Christology of any Nestorian tendencies, and is adopted by the Fifth Ecumenical Council as the proper interpretation of Chalcedonian Christology (Price 2009a, 73). T.F. Torrance explains the distinction as follows. Anhypostasia claims that "Christ's human nature has its existence only in union with God, in God's existence or personal mode of being (hypostasis). It does not possess it in and for itself-hence an-hypostasis ('not person', i.e. no separate person)." Enhypostasia expresses the fact that "the human nature of Christ is given existence in the existence of God, and co-exists in the divine essence or mode of being" (Torrance 1988, 84). These definitions from Torrance can cause some confusion because he seems to blur the distinction somewhat. Sometimes the distinction gets a bit muddled in contemporary discussions because of the mutually confirming nature of each claim. In other words, the claims are meant to work together. So a bit of clarification is called for.

The enhypostasia claim is that the Son's human nature only exists because of the incarnation. The anhypostasia claim seems to contain two conditions. First, the Son's human nature would not have existed if it were not for the incarnation. This is incredibly similar to the enhypostasia claim, but anhypostasia adds a further condition. The second condition is that the human nature is only personal because it is assumed by a divine person-i.e. God the Son. The human nature is not, nor could have been, a person independent of the Son's assumption (Brown 2011, 24). ${ }^{4}$ Fred Sanders explains that this is where the strength of the enhypostasia and anhypostasia distinction comes into play in riding ecumenical Christology of Nestorianism. It excludes the very possibility that the human nature of Christ could have formed some person, call him "Adam Davidson Ben-Msriam," from coming into

\footnotetext{
${ }^{3}$ See Kelly $(1958,340-2)$.

${ }^{4}$ Cf. Craig (2006, fn. 16).
} 
existence if the Son had not assumed this nature (Sanders 2007, 30-35). The human nature of Christ cannot form a person apart from the incarnation. The human nature is only a person because it is assumed by the person of the Logos. The human nature only exists because of the incarnation.

The take away from this is that TMP is not consistent with orthodox Christology. It flies in the face of the theology of the Fifth Ecumenical Council. TMP says that CHN could have formed a human person if it were not assumed by the Son. The enhypostasia and anhypostasia distinction teaches that CHN could not have formed a human person without the assumption. Further, CHN would not even exist without the incarnation. So TMP is false given orthodox Christology.

TMP is the basis for Flint's 6 Radical Theses. Since TMP is unorthodox, Flint's Radical Theses rest on a foundation that must be rejected by Christians who are committed to the ecumenical tradition. Flint claims that he is committed to the ecumenical creeds, so Flint must give up TMP. To make matters worse for Flint, the enhypostasia and anhypostasia distinction goes directly against several of Flint's Radical Theses.

Consider Thesis 1: Necessarily, being assumable is a contingent feature of any assumable human nature. The Christology of the Fifth Ecumenical Council teaches that CHN was created explicitly for the incarnation, and that it would not have existed otherwise. It seems prima facie plausible that being assumable is a necessary feature of CHN, and only CHN, on this Christology. Thesis 1, then, is not clearly consistent with the Christology of the Fifth Ecumenical Council.

Thesis 2 says that it's possible that CHN was neither assumed nor assumable. Recall again, that CHN is a concrete particular. Flint is not talking about an abstract nature. He is explicitly talking about a concrete individual. Thesis 2 is saying that this concrete particular could exist, and not be assumed. Further, CHN could exist, and not be assumable due to being in a world in which CHN sins. Thesis 2 is explicitly denied by the anhypostasia and enhypostasia distinction. The distinction teaches that it is not possible for CHN to exist and not be assumed. Thesis 2 must be rejected by Christians who wish to be consistent with the teachings of ecumenical Christology. Again, Flint claims to be committed to the teachings of ecumenical Christology, so Flint must give up Thesis 2.

Thesis 4 says that it is possible that CHN exist as an independent, unassumed suppositum. As explained above, Thesis 4 is saying that CHN could exist as a human person without the incarnation taking place. Say God actualized World B in which CHN is not assumed by the Son. CHN is a human person distinct from the second divine person. CHN is a human person, born of the Virgin Mary, who proclaims the coming of God's kingdom. Unfortunately for Flint, this is the precise state of affairs that the Fifth Ecumenical Council sought to reject. The Christology of the Fifth Ecumenical Council outright denies Thesis 4.

It is not obvious to me that the enhypostasia and anhypostasia distinction are in direct opposition to Theses 3, 5, and 6. So I do not claim to have refuted Flint's entire Christological proposal. I do not think it would take much argument to show that 5 and 6 are inconsistent with ecumenical Christology, but that is unnecessary 
for my purposes in this paper..$^{5}$ All I am claiming is that I have significantly undermined Flint's Christology by showing that TMP, and Theses 1, 2, and 4 are false according to ecumenical Christology. Flint is mistaken when he claims that his account is consistent with the ecumenical teachings, and is further mistaken in claiming that his account is, in part, motivated by the ecumenical teachings.

\section{The Theory of Final Assumption Violates the Teachings of the Fifth Ecumenical Council}

One will recall from above that Flint uses TMP and his 6 Radical Theses to motivate his Theory of Final Assumption (TFA). By now it should be clear to the reader that TFA is unmotivated because TMP and several of the Radical Theses are false on ecumenical Christology. In this section, I shall argue that TFA is also false given the ecumenical teachings.

One will recall that on TFA all sanctified human persons will one day be assumed by God the Son. We will all become incarnations of God. At that point we will all cease to be persons. All of sanctified humanity will be one person-God the Son. The human natures that once constituted human persons will remain human natures. They will simply fail to constitute human persons once they are assumed by the Son. What seems to have gone unnoticed in discussions of Flint's eschatology is that it looks remarkably like the heresy of Origenism. Origenism is explicitly condemned by the Fifth Ecumenical Council. 6 To be clear, I am not saying that Flint is an Origenist. As I shall discuss below, there are some clear differences between Flint's account and Origenism. However, I shall argue that Flint's account is a type of Origenism in a new garb. It is Origenism 2.0-a heresy for a new generation. In order to see that Flint's Christology and eschatology is Origenism 2.0, the original heresy will need to be articulated first.

The heresy of Origenism is quite fascinating in and of itself, though it is debatable how much of it is based in the actual theology of Origen. Several different Origenist schools of thought develop during the early Church, and a major controversy arose over Origenism in the $6^{\text {th }}$ Century. In 543 the emperor Justinian issued multiple anathemas against the teachings of Origenism, followed by a condemnation of Nestorianism about a year later. This reflects a growing conviction among certain factions during this time period that there is an implicit connection between Origenism and Nestorianism. Each Origenist school of thought has different nuances, and it is not always clear that the anathemas accurately portray the actual views of theologians in the Origenist schools. So it can be difficult to figure out

\footnotetext{
${ }^{5}$ One could develop the many arguments against adoptionism and Nestorianism that exist in the early Church to establish that 5 and 6 are inconsistent with ecumenical Christology.

${ }^{6}$ It used to be a matter of dispute amongst church historians as to whether or not the condemnations against Origen were a part of the Fifth Ecumenical Council. Some older English translations of the documents and proceedings of the Council leave out the anathemas against Origen. This is no longer in dispute since we have good evidence for the anathemas being decided upon at the beginning of the Council. Cf. Price (2009b, 270-272).
} 
which school Justinian has in view. However, the schools each contain several core claims that unite them, so it could very well be that he is issuing a blanket condemnation of all Origenist thinking. This is plausible given that patriarchs in Jerusalem and Antioch were calling for the emperor to condemn Origen himself. (It would be similar to the condemnations against Arianism in prior generations where many different groups were somewhat awkwardly lumped into the same category as Arius.) In 553, Justinian issues an updated set of anathemas against Origenism, and the Fifth Ecumenical Council develops its own as well. These multiple canons against Origenism also contain several nuances and expansions from previous condemnations, giving us a fairly clear picture of the different core teachings that were considered heretical. It also gives us a better idea of which Origenist school might have been in view (Price 2009b, 272-286).

So what are these core heretical claims? The heresy of Origenism tells a story of pre-existent souls falling from grace and taking on bodies. One soul, however, remains faithful to God and never sins. The Logos unites Himself to this one soul that never sins, takes on a human nature, and redeems humanity. At the eschaton, all souls will be united to the Logos in such a way that they lose their identity and all become one hypostasis (person). Sound familiar? It should. This sounds strikingly like Flint's Christology and eschatology.

Again, Origenism is condemned at the Fifth Ecumenical Council. Second Constantinople's 14th Anathema against Origen goes as follows: anyone who says that all reasonable beings will one day be united in one hypostasis will be anathema. The anathema is speaking against the claim that all souls will become one, that bodies will cease to exist, and that the souls will all lose their names as they all take on the identity of the one hypostasis/person. ${ }^{7}$

Flint's account does have some important differences from Origenism. First, Flint does not believe in pre-existent souls that fell from grace. Second, Flint never says that human bodies will cease to exist. Third, Flint never says that humans will lose their names. We will still be able to refer to each other by name, and speak of ourselves in the first-person. So Flint's account is not obviously Origenist on these issues.

But the similarities between Flint's account and Origenism are, unfortunately, damning. Though Flint's account is not identical to Origenism, it looks like the core claims of Flint's account are condemned by the Fifth Ecumenical Council under the banner of Origenism. I shall examine two core claims of Flint's account that seem to be condemned at this Council.

First core claim: all will be hypostatically united to the Son. Flint's account clearly proclaims things that are anathematized by the Fifth Ecumenical Council. In particular, the claim that all human persons are united to the Son in such a way that there is only the divine person is clearly anathematized. Flint's account quite explicitly teaches what is being anathematized here. On Flint's eschatology, all human persons will be assumed by, or hypostatically united to, God the Son. These

\footnotetext{
${ }^{7}$ For a highly condensed copy of the proceedings, declarations, and anathemas of Constantinople II, see http://www.fordham.edu/halsall/basis/const2.asp. For an exhaustive copy see Price (2009a, 2009b).
} 
human persons will lose their personhood in the identity of the Son. This is explicitly condemned in the $14^{\text {th }}$ Anathema against Origen. Contrary to what Flint maintains, his eschatology is not compatible with the ecumenical teachings. Since it is not compatible with the ecumenical teachings, it cannot gain any motivation from the ecumenical teachings either.

Flint might have a possible rejoinder. He might say that the anathema is condemning the conjunction of all the teachings mentioned. It does not condemn the teachings individually. Since Flint is only affirming one of these teachings, and not the conjunction of all the Origenist teachings, he does not run afoul of the anathema. ${ }^{8}$

This is an interesting rejoinder, but it is implausible. The individual teachings themselves cause problems for Christian belief. In Justinian's letter to the council, he explains why condemning "Origen and those like-minded" is a matter of urgency. He discusses why the various teachings cause problems for Christian theology. With regard to the claim that all will become one hypostasia with Christ, Justinian complains that this destroys the uniqueness of Christ. If all human beings become hypostatically united to the Logos, "there will be no difference at all between Christ and the remaining rational beings, neither in substance nor in knowledge nor in power nor in operation" (Price 2009b, 283). This is an important point to emphasize for it is not simply the conjunction of various Origenist teachings that is odious to Christian thought. One of the main contentions of orthodox theology is that the incarnation is an utterly unique event. Flint's eschatology, as well as the Origenist's eschatology, guts the uniqueness of the incarnation by expanding it to all of humanity. This is something that Justinian and the Fifth Ecumenical Council wish to reject. Instead, they wish to maintain the eternal uniqueness of the incarnation.

Second core claim: the Son elects to be united to a person who is free from sin..$^{9}$ Flint claims that God uses His middle knowledge to know which possible human person will not freely sin. One might complain that I am being uncharitable because this possible human nature that God is examining via middle knowledge is not a possible human person. Instead, one might say, it is merely a possible human nature. But I don't think that is right. What God is supposedly doing via middle knowledge is examining which possible human persons are prime candidates for assumption. God does not elect to assume a particular human nature until He finds a suitable candidate. Once God finds a suitable candidate, He elects to actualize a world very similar to the one in which the suitable candidate never sins. I say 'very similar' because there is one significant difference between the world that God examines, and the world that God actualizes. In the world that God examines, no assumption takes place, and the candidate is a person who never sins. In the world that God actualizes, the Son assumes this candidate. It is only when the assumption takes place that this candidate fails to be a person.

\footnotetext{
8 Thanks to a referee for pointing this out to me.

${ }^{9}$ This claim is not unique to Origenism. It is also a core claim of certain Nestorian groups who say that the union of God with man took place by God's good pleasure, or excellent opinion of a man. Cf. Price (2009a, 144).
} 
It is true that Flint's Christology and eschatology do not clearly map on to Origenism on this point, but I say that it is close enough to be highly suspect, and close enough to be considered heretical. Again, Origenism 2.0-a heresy for a new generation. On Flint's account, the Son is considering which possible person to assume. The Son picks a possible person who will not sin. The Son unites Himself to this person in such a way that there is only one person because of the union. That is too close for comfort as it looks too much like a refashioned Origenism. This, I maintain, is enough to show that this aspect of Flint's account it unmotivated by the ecumenical teachings as well.

Overall, Flint's Christology and eschatology is not compatible with the ecumenical teachings, nor is it motivated by the ecumenical teachings. If Flint wishes to be in line with the ecumenical tradition, as he claims, he will need to abandon his Christological and eschatological proposals.

\section{Prolegomena for Future Models of the Incarnation}

Flint's recent paper is motivated by the question of multiple incarnations. Flint points out several possible motivations for multiple incarnations, and examines a motivation from Molinism. He notes, but does not endorse, that one motivation for multiple incarnations is the possibility of life on other planets. The idea is this. What if something like C.S. Lewis' space trilogy were true? There are different planets in our universe that have intelligent life. On some of those planets, creatures have fallen from grace and are in need of salvation. Do these creatures need an incarnation? One possible answer is yes. These creatures will need their own incarnation in order to be redeemed.

If one wishes to argue this case, one is free to do so. However, such a person must not consider herself to be in line with the ecumenical teachings. The Fifth Ecumenical Council contains multiple anathemas against similar notions. The 4th Anathema against Origen from the emperor Justinian condemns views where the Son became incarnate in a series of multiple bodies in order to save different classes of creatures.

The reason I bring this up is similar to my reason for critiquing Flint's account of the incarnation. Many Christological discussions in contemporary analytic philosophy of religion proclaim to be following the ecumenical creeds, but in fact they are doing no such thing. Such discussions typically revolve around the claim that the Son was one person, fully human, and fully divine. This is certainly part of the ecumenical teaching, but there is more to the story. Analytic philosophers of religion quite often ignore the rest of the details of the ecumenical teachings. For instance, those who deny divine impassibility proclaim that they are still in line with the teachings of Chalcedon despite the fact that impassibility is explicitly endorsed at the Council.

Now that analytic philosophy of religion has spawned the analytic theology movement, the time seems ripe to ask some difficult and probing theological questions. Those explicitly trained in theology must raise issues that Christian 
philosophers do not seem eager to consider, and employ the analytical rigor that they have learned from the philosophers of religion. Two questions in particular need to be addressed. First, what authoritative status should we give to the creeds, and why? Second, which creeds should we give authority to, and why?

With regard to the first question, analytic Christian philosophers seem to treat the creeds very differently than various contemporary theologians. John Hick points out that, unlike most contemporary theologians, analytic Christian philosophers tend to see ecumenical doctrine as a set of immutable truths (Hick 2013, 372-373). True, there are a good number of theologians who treat the creeds in this way, but it is by no means the status quo as it seems to be amongst Christian philosophers.

Several contemporary church historians see the ecumenical creeds as a series of failed attempts to produce a coherent Christology, and unite the churches. ${ }^{10}$ Contemporary systematic theologians like Robert Jenson and David Brown agree that the conciliar creeds are not obviously coherent, and that they are failed attempts at reaching a compromise of diverse Christological theologies (Jenson 2002). Brown, for instance, quite explicitly says that we can ignore some of the details of the creeds, and focus on what all sides seem to be reaching for-the claim that Jesus is one person in two natures (Brown 1985).

Conservative evangelical theologians like Augustus Strong state that we are people of Christ, and not people of the creed. The ultimate authority lies in Christ, and a derivative authority lies in the inspired scriptures. "We must remember that creeds are...historical statements of what the church has believed, not infallible prescriptions of what the church must believe." If the creeds lead us away from the clear gospel teaching, then we must follow the gospel instead (Strong 1907, 18).

Even fairly conservative New Testament scholars like Richard Bauckham criticize the creeds for imposing a Greek ontology onto the gospels instead of employing the biblical categories used to describe the incarnation (Bauckham 2008). In light of such things, what is the analytic theologian to do?

To be clear, I am not giving an endorsement for analytic theologians to abandon the creeds. Nor am I endorsing analytic theologians to treat every detail of the ecumenical teachings as gospel truth. Rather, I am making a call for analytic theologians to articulate clear positions towards the creeds, and offer good reasons for giving the creeds whatever authoritative status they think the creeds should have. As it stands, there doesn't seem to be a principled way to work through this.

With regard to the second question, it is not at all clear which creeds should be considered authoritative for future work in analytic theology. Analytic theologians come from a variety of church backgrounds. The Catholics and Eastern Orthodox will agree that the seven ecumenical councils should be given infallible authority. However, Catholics are going to consider many later councils and synods to have authority that Eastern Orthodox theologians will not. Protestants, as always, are a tricky bunch. The 39 Articles of the Church of England gives authoritative status to the Apostle's Creed, the Nicene Creed, and the Athanasian Creed-the Nicene Creed being the only ecumenical creed on the list. Reformed theologians

${ }^{10}$ The Oriental Orthodox churches still reject Chalcedon to this day. 
tend to favor confessions and catechisms from Dort and Heidelberg. Evangelicals are all over the map. Some only affirm the first four ecumenical creeds, whereas other evangelicals go in another direction by affirming all seven ecumenical creeds plus "the tradition." This recent trend amongst evangelicals is a move towards a hypertraditionalism that seems to mirror certain forms of Catholicism, but with a different list of "holy doctors" of the church. Sure, these evangelicals give Aquinas the same authoritative status as the New Testament, but they also extend that authoritative status to the Protestant scholastics as well. Francis Turretin has just as much authority as Aquinas and the Council of Chalcedon. On the other end of the spectrum, there are smaller Protestant traditions like the Restoration Movement who affirm "No Creed but Christ." Theologians from the Restoration Movement tend to be a bit skeptical of "the tradition," but typically express some sort of commitment to the early Church Fathers. To complicate matters even more, T.H. Green offers the following tongue in cheek comment on the theologian's supposed commitment to the tradition. "We are told that we must be loyal to the beliefs of the Fathers. Yes, but who knows what the Fathers believe now?" (Strong 1907, 19). In the midst of such disagreement, what is the poor analytic theologian to do?

It is time for analytic theologians to start discussing reasons for giving creeds some type of authority, if any. Analytic theologians need to develop ways to discern which creeds should have authority. Perhaps it is a pipe dream to think that this will help clear up various issues in philosophical theology, but as it stands now, there is quite a bit of confusion. At the very least, such discussion amongst analytic theologians would not make the contemporary confusion any worse as far as I can tell. 11

\section{Bibliography}

Bauckham, Richard. 2008. Jesus and the God of Israel: God Crucified and Other Studies on the New Testament's Christology of Divine Identity. Grand Rapids: Wm. B. Eerdmans Publishing Co.

Beeley, Christopher A. 2012. The Unity of Christ: Continuity and Conflict in Patristic Tradition. Yale University Press.

Brown, David. 2011. Divine Humanity: Kenosis and the Construction of a Christian Theology. Baylor University Press.

Brown, David. 1985. The Divine Trinity. Open Court Publishing Company.

Coakley, Sarah. 2002. "What does Chalcedon Slove and What does it not? Some Reflections on the Status and Meaning of the Chalcedonian 'Definition'." In The Incarnation: An Interdisciplinary Symposium, edited by Stephen T. Davis, Daniel Kendall, and Gerald O’Collins. Oxford University Press.

${ }^{11}$ I would like to thank J.T. Turner and an anonymous referee for helpful comments on earlier drafts of this paper. 
Craig, William Lane. 2006. "Flint's Radical Molinist Christology Not Radical Enough," Faith and Philosophy 23: 55-64.

Cyril of Alexandria. 1980. "Second Letter to Nestorius." In The Christological Controversy, edited by Richard Norris. Minneapolis: Fortress Press.

Flint, Thomas P. 1998. Divine Providence: The Molinist Account. Cornell University Press.

Flint, Thomas P. 2001a. "'A Death He Freely Accepted': Molinist Reflections on the Incarnation." Faith and Philosophy 18 (1): 3-20.

Flint, Thomas P. 2001b. "The Possibilities of Incarnation: Some Radical Molinist Suggestions." Religious Studies 37 (3): 307-320.

Flint, Thomas P. 2011. "Molinism and Incarnation." In Molinism: The Contemporary Debate, edited by Ken Perszyk. Oxford University Press.

Hick, John. 2013. "Problems with the Doctrine of Atonement." In Debating Christian Theism, edited by J.P. Moreland, Chad Meister, and Khaldoun A. Sweis. Oxford University Press.

Jenson, Robert W. 2002. "With No Qualifications: The Christological Maximalism of the Christian East." In Ancient and Postmodern Christianity: Paleo-Orthodoxy in the $21^{\text {st }}$ Century, edited by Kenneth Tanner and Christopher A. Hall. InterVarsity Press.

Kelly, J.N.D. 1958. Early Christian Doctrines. London: Adam and Charles Black Limited.

Price, Richard. 2009a. The Acts of the Council of Constantinople of 553 with Related texts on the Three Chapters Controversy, Volume 1. Liverpool University Press.

Price, Richard. 2009b. The Acts of the Council of Constantinople of 553 with Related texts on the Three Chapters Controversy, Volume 2. Liverpool University Press.

Sanders, Fred. 2007. "Introduction to Christology: Chalcedonian Categories for the Gospel Narrative," In Jesus in Trinitarian Perspective, edited by Fred Sanders and Klaus Issler. B\&H Publishing Group.

Strong, Anthony Hopkins. 1907. Systematic Theology: Volume 1 The Doctrine of God. American Baptist Publication Society.

Torrance, Iain. 1988. Christology After Chalcedon: Severus of Antioch and Sergius the Monophysite. Wipf and Stock Publishers. 
Torrance, Thomas F. 2015. Incarnation: The Person and Life of Christ. IVP Academic. 